\title{
Lockdown Reflections on Freedom and Cultural Intimacy
}

\section{Michael Herzfeld}

\begin{abstract}
АвsтRAст: In this article I address the role now being played by libertarian attacks on the enforcement of health regulations such as the wearing of masks. I suggest that a kind of cultural intimacy now emerging may take the form of guilty but willful complicity in a libertarian stance, not for reasons of social solidarity or collective freedom but for a NIMBY-like selfishness. That attitude constitutes a larger threat to society and is cultivated by racist and other hate-directed groups often sheltering behind bullying national leaders. These groups adopt the libertarian rhetoric and nationalist tropes of concern to protect individual freedoms, whether in the United States or the United Kingdom. The article ends with an appeal for anthropologists, in particular, to respond by framing a more socially conscious vision of freedom.
\end{abstract}

KeYWORDs: bullying, cultural intimacy, fascism, libertarianism, NIMBY, pandemic

I am not an expert on COVID-19. I hope never to become one. Partly this is because a COVID-19 expert is someone who has had (or still has) COVID-19. I am inspired to make this categorical assertion by James Thurber's (1994) sage observation that 'a dog lover is a dog in love with another $\operatorname{dog}^{\prime} .{ }^{1}$ My refusal to be a COVID-19 expert springs from my irritation with the current proliferation of self-declared experts on everything from viruses to violence and from refugees to recycling. This expansion of claims to arcane knowledge may already have brought the very idea of expertise into terminal disrepute. Too many selfproclaimed experts, armed with NGO or academic credentials, and largely dependent on local intermediaries and interpreters for any kind of insight at all, have produced too many reports that politicians and policy-makers read selectively or simply ignore. ${ }^{2}$ This is a trebly damaging situation: it breeds insecurity about what information to trust; it feeds populist hostility towards experts who really do know what they are talking about; and it offers politicians a figleaf for their ignorance.

Expertise has especially suffered by becoming the easy target of angry right-wing propagandists keen to displace what they view as faux knowledge with their own competitive brand of ignorance. (Neoliberalism is not solely about money; ever since William O. Douglas coined the phrase 'the marketplace of ideas', the stock-exchange model of competitive unknowing has spawned increasingly phantasmagoric mutations of dangerous idiocy.) As anthropologists, we can study the phenomenon, even doing so as participant observers, but we should avoid pontificating on matters on which we have no ethnographic or other experience.

What I can do is focus on what I know. That is what real experts do. There is, were one willing to face it, a direct link between the intimacy of lockdown and its attendant inconveniences and advantages on the one hand, and, on the other, the intimacy of a country - the United States - that is famous for its technology but seems now unaccountably beset by massive failures of political and administrative nerve. One aspect of this collapse is a crisis of confidence in expert knowledge, a crisis of which a populist president has been all too eager to take advantage. In his purview, no form of expertise can be spared the searing light of comparison with his own personal experience, 
as witness his promotion of ingesting an antiseptic cleanser as effective protection against the coronavirus. His inept handling of the pandemic crisis places the economically most powerful country in the world even lower down in the list of crisis management achievement than his leadership has already sunk it in the press freedom charts.

Why does support for that leadership still seem, while reduced, substantial enough to threaten a secondterm presidency? Those of us who have not grown up in the United States are particularly puzzled that the president still has any support at all, but Americans who have never liked his abrasive style are often indignant that he still has a following. The answer is clearly not with those who, like Hillary Clinton in the 2016 election, regard his followers with contempt as, in Clinton's words, 'a basket of deplorables'. That refusal of humanity to groups of citizens who felt themselves dispossessed and misunderstood not only may have cost her even the chance of victory, it also invited a contest of prejudice between the two sides that those who were more practised in hate-mongering and racist innuendo could hardly fail to win.

Another part of the answer to Donald Trump's victory, however, lies in the unique international stature of the United States. It is arguably the only country that is truly both imperial and post-colonial at one and the same time. This endows it with both a sense of the power to lead the world ('manifest destiny') and a collective chip on the cultural shoulder. The power is certainly still real, if dwindling. But it may be the first time that a significant number of Americans realise that other, less wealthy nations are viewing its distress with pitying Schadenfreude, that toxic mixture of contempt and derision that shows where cultural power really lies, but also that it is vulnerable (see Collinson and $\mathrm{Hu}$ 2020). This condescension feeds greedily on images of the 'ugly American', who, as an object of foreign revulsion, became the symbol and embodiment of what I call 'cultural intimacy'. ${ }^{3}$ Perhaps this, the crumbling of cultural intimacy's defences, is what theorists of revolution and social change have missed until now. Is it that revolt surges when people realise that they can no longer rely on the state or other institutional structures to protect their right to be uncouth, naughty, mildly criminal or simply irreverent?

Cultural intimacy is that zone of collusion in which ordinary people break social norms with a guilty but shared sense of pleasure. What do people do when government (at whatever level) cracks down hard and destroys that intimate space on which its own survival depends (tolerance being a necessarily mu- tual attitude, admitted or not)? And - perhaps more to the point - what do potential revolutionaries do when the government starts making statements that suggest that discretion is no longer necessary and that it is now acceptable - even if with a certain sly indirection - to invoke racist and sexist stereotypes in political speech? If the first case is represented by harsh dictatorships, some of which have indeed cracked under the weight of their own humourless intolerance of minor dissent (see Glaeser 2004), the second is arguably represented by Trump's (decreasingly) United States and, more subtly perhaps, by Boris Johnson's (not very) United Kingdom. I would not put the Confederate flag and Scots nationalism in the same political category, but the fact that both have enjoyed resurgent visibility under these populist leaders suggests that the cat is out of the bag that the hitherto unacceptable, politically incorrect 'everyday ethics' of the usually silent majority have slipped from secretive locker-room giggles to in-yourface aggression. ${ }^{4}$

We watch this unravelling of a hitherto privileged collective intimacy from constricted physical space and a distorted temporality. Lockdown, traversed by multiple channels of electronic communication, has produced its own peculiar impact. A phenomenon many of us share, we discover in the chattier moments of Zooming with colleagues and friends, is the awareness of how unaware we have become of time's passage. As days merge with weeks and weeks with months, temporality seems to have lost its ability to remind us constantly of the value of being alive, and we have to look to other reminders: personal intimacy, to be sure, and creative activities like cooking, music and writing.

Under these limiting circumstances, I actually know very little about how Americans are dealing with their collective embarrassment other than that it exists. I do know that those who do not support the current behaviour of their government feel a moral obligation in this regard; they admit to feeling embarrassed, and for good reason. And while the American media have themselves expressed a fair amount of Schadenfreude (a useful attitude in the game of international tit-for-tat) at the plight of the United Kingdom, they do seem understandably preoccupied with their own difficulties.

Although I am a British citizen, I have no reason to feel that their attitude is baseless; indeed, it is reciprocated. I have lived in the United States long enough to feel embarrassed with them, but I am also aware of the embarrassments of a Brexit-mired United Kingdom. This at least now allows me to experience a 
couvade-like empathy at the birth of self-awareness that such desperate yearnings to share the misery indicate. I also fear that whenever Trump makes his objectionable, snide remarks about 'kung flu' or 'the Wuhan virus', some US citizens, in secret discomfort, feel that the Chinese deserve this - if the Democrats win the November election, they are not going to become pro-Chinese overnight - and that the only reason China has fared better with the virus of late is that it has such an undemocratic way of doing things. That may be true, although recent events raise chilling questions about the future of democracy in the United States (and, for that matter, about the unequal distribution of its benefits up to the present). But my point is a different one: that this racist rhetoric connects all too easily with the seemingly care-free, happy-go-lucky rhetoric of the anti-maskers. It is much easier to blame the Chinese than to question one's own unwillingness to wear a mask, beyond the usual excuse that it is un-American (shades of McCarthy here!) to require people to do so because it impinges on their personal freedom.

That, in a nutshell, is the main issue. The antimaskers have battened onto a traditionalist rhetoric that invokes the foundation of their country and an individualistic ethos of liberty. Note, however, that this is about personal rather than collective freedom. It is easily connected to the infamous NIMBY ('not in my back yard') attitude - a refusal to share risks posed by a range of unwanted interventions including toxic waste but also socially undesired neighbours and services - towards centralised urban planning. ${ }^{5}$ And while it may superficially resemble the pursuit of personal freedom (itsaraphap) that leads impoverished Thai farmers to follow physically dangerous and politically charged professions in the national capital, that freedom is still linked to the ability to earn money to support the care of elderly parents and deprived siblings back home (Sopranzetti 2017). These impoverished ex-farmers have a powerful sense of the moral obligation to support others, also demonstrating a strong sense of mutuality and generosity to each other, which is lacking in the comfortable middle-class urbanites who regard these former peasants as condemned by their karma to a permanent inferiority.

When people pursue only self-interest, they create the conditions under which racism and classism become acceptable. Self-interest is also blind to the future: 'It can't happen here' is the usual response to any talk of coups, pogroms and concentration camps. But as the son of refugees from Nazi Germany, and perhaps consequently - as an anthropologist, I am aware that racism can happen anywhere, and especially when people say that it could not happen in a particular country. When my undergraduate adviser in England told me that a spell in Auschwitz would do me good, I realised that polite or jocular racism could be the most insidious of all. It was hard to answer at the time (though a good friend wished I had said that some of my relatives had tried that method and found it rather extreme). Prejudice flourishes where its existence is denied.

It also takes many forms, and it is easily provoked by attitudes of cultural superiority. It is easy, for example, to understand the post-colonial bitterness that has so many Americans reacting resentfully to the sound of the upper-class British accents they so affect to admire - an admiration that also partly explains the resentment. Such is the nature of post-colonial attitudes, and, while the idea might be distasteful to some Americans, these are as deeply entrenched in the United States as in Nigeria or India. Indeed, one might also ask what right I have, as a 'Brit', to call the most powerful country in the world 'post-colonial'? But freedom of expression and especially of cultural critique is not the same as the freedom to use hate speech. Cultural critique invites mutual engagement; hate speech refuses it. The issue is thus one of how far one is willing to take responsibility for one's opinions; and the 'methodological nationalism' that engenders questions about foreigners' rights to engage in such critique can itself deteriorate very easily into a form of prejudice or even racism. ${ }^{6}$

As I experience the curious temporality of lockdown and read the news, day by day, of the humiliation of both the United Kingdom and the United States, while also getting on with the press of work on my desk, I find myself reflecting on how the pandemic has upended conventional views of power. There is no doubt about the American sense of humiliation, and it fuels both the attacks on Trump and the fury of his supporters. But there have been other, more global ripples too, and these may be of greater geopolitical significance in the long run. (What? The United States will not always be at the center of attention?) Take the case of Greece, a country where I have conducted my most extensive research. While Brexit has rendered the United Kingdom economically helpless and COVID-19 seems to be finishing off the job, the bad child of the European Union - even under a stalwartly neoliberal leader - has pulled a big surprise. Greek diplomats and journalists are expressing pride that this time, at least, their country has apparently done, not just the right thing, but the disciplined thing. They are certainly entitled to bragging rights laced 
with the sweet taste of vengeful reciprocity; but if I were a Greek I would be spitting in all directions, the best-known Greek defense against the evil eye. Greece has for too long been the favourite victim of Western European bullying for its insolence in pulling off such a dramatic success to be allowed to stand.

But Greece has some other, less well-known achievements to celebrate. The neo-Nazi party called 'Golden Dawn', which at one point had 18 deputies in the National Parliament, lost all its seats in the last election and several of its leading lights have been sentenced to substantial prison terms for murder and other forms of violence. More significantly, perhaps, many of the solidarity movements that have sprung up in a country long known for its intense nationalism have supported and protected 'illegalised' migrants from a hostile police apparatus long suspected of being infected with the virus of Golden Dawn (De Genova 2017; Rozakou 2017). Is there, one wonders, a link between the sense of social obligation - ipokhreosi, a term etymologically cognate with khreos ('debt') and denoting a concept that underlies the Greeks' deep resentment of their treatment by their international creditors over the past dozen years - and the capacity to achieve solidarity with the outsider, the recipient of an always-conditional and forever demonstrative hospitality?

Conversely, is it the self-absorption of imperial countries like the United Kingdom and the United States that tolerates structural violence - crowded living conditions, limited financial resources, high unemployment - against minorities in times of pandemic, and redoubles that violence by using it as a reason for targeting those minorities as consequently more likely to spread the disease (see particularly Santiago 2020). Does gated NIMBY individualism enhanced by the systemic selfishness of neoliberalism so destroy that capacity for empathy that libertarianism wins the day and clears the space for unrestrained racism? On both sides of the Atlantic, the freedom of speech - or, more generally, 'freedom' - that is so passionately defended by libertarians is not a social freedom. It is a selfish freedom: freedom to own guns; freedom to run amok and slaughter schoolchildren and housewives; freedom to spout hate-laden obscenities; freedom to infect others through active disregard - nay, denial - of elementary hygienic measures.

Lockdown may not impede, and may indeed magnify and spread, the sweaty adolescent masculinity that one associates with particularly nasty forms of racism. After all, it is an imposed privacy for which libertarians and hard-core rightists alike would see no reason to assume any responsibility. There, I fear, an immature maleness may resuscitate the less attractive aspects of high-school life, where surreptitious giggles and guffaws and bully-boy tactics on the playground create the complicit intimacy that then, repeated over and over, becomes cultural. 'No, sir, we didn't do that,' say the perpetrators, safe in the knowledge that authority offers only weak protections against their bullying. Nor would the bullied victim accuse them; it would be too dangerous dangerous, that is, not because the victim would get beaten up again (he would anyway), but because the mortification of being seen as a sneak might even be intensified by some unsympathetic Arnoldian headmaster telling him to 'be a man'. Such attitudes, cultivated in the privacy of lockdown, may again become the substance of a virulent form of cultural intimacy on the public stage. Indeed, this has to some extent already happened.

But masculinity, which I have studied in the Cretan highlands, is not necessarily about bullying (see Herzfeld 1985; and Kalantzis 2019). Political leaders who mistake bullying for leadership fail to distinguish between the two; and every sycophant who reinforces their fragile egos is, willy-nilly, refusing to consider such a subtle refinement, dismissing it as sissy, or academic, or just too complicated. Cretan village men abhor cowardice, and they know that bullying is a form of cowardice. They tend to respect the quiet, tough man who, just occasionally, will use force or pull political muscle. But they look down on the loudmouth who cannot deliver and runs away after uttering threats, or who allows authority to do his dirty work for him. The Trumps and Johnsons of this world would not survive long in that village. They would not be killed, or even beaten up (unless they did something stupid even by their standards). They would be humiliated by laughter, ostracised with knowing smiles, belittled through pity. That is what has happened to the United States, erstwhile bully in the global schoolyard.

Under lockdown, my empirical evidence lies almost entirely in reading media reports. Yet that is sufficient to fuel the suspicion that awareness of growing international humiliation feeds a defiant libertarianism, so that the anti-maskers can claim that they are rescuing the individualistic ethos of pioneering (White) America from the evil (leftist and un-White) bogey. Better, so the implicit argument goes, to die of this terrible sickness than to surrender cravenly to the demand for social consensus (otherwise known as Obamacare, socialism and political correctness). These demonstrators are deeply suspicious of experts 
of any kind; here, we are talking about opposition to a genuine expertise that knows its own limitations and confronts them - as Dr. Anthony Fauci did when responding to the charge that he has changed his advice to the American people.

Fauci's stance is that of a true scientist. The scientist knows that all knowledge is imperfect, provisional and conditional. Unfortunately, libertarians and racists see such a position as weak, and so they reject it under the leadership of a bully who still claims to 'have a very good relationship with' Dr. Fauci rather than engaging him in a serious national discussion (see Holmes and Cole 2020). Thus it is that someone apparently lacking any training in medical science, White House economics adviser Peter Navarro, can pronounce on the expertise of the health specialists, using the prefix 'doctor' to assume an air of unchallengeable authority (see, for example, Rogers 2020). Because Trump wants to 'open up' the economy, his acolytes must conspire to act as though the pandemic was already disappearing.

I do not propose to speculate here on why a president who claimed that he never expected to win the 2016 election seems grimly determined to win in 2020, although one is entitled to guess in light of the many unresolved legal issues that he will face when he does step down. But if he claims victory in November, it will not matter much - in terms of his own career - that he will have failed to lead his country through this terrifying experience. If the libertarians are endowed with any intelligence at all, they must realise that, in taking up their cause on the issue of masks and quarantines and dressing it up as a fight for personal freedom, they are aiding and abetting what has become the greatest threat to collective freedom freedom from disease, freedom from censorship, freedom from random acts of hatred - to have appeared in the United States and globally in many decades. Perhaps they do know, but we have no way of determining the extent to which they are consciously complicit.

So my suspicion, on entirely circumstantial evidence, is that the cultural intimacy being defended here is a guilty realisation that people are citing freedom to excuse a selfish reluctance to give up convenience and pleasure for the greater good. In this regard, it behooves us to think (as anthropologists should) comparatively, and to compare their attitude with that of politicians around the world who are exploiting the pandemic for similarly unattractive purposes.

It is increasingly evident that some national leaders see in the pandemic a golden opportunity to ramp up real restrictions on freedom and to consolidate their own power. Prayuth Chan-ocha in Thailand, Rodrigo Duterte in the Philippines, Viktor Orbán in Hungary and perhaps others who have been able to impose strict curfews and intensified street surveillance are doubtless benefitting from this opportunity (Gebrekidan 2020). In Thailand, in particular, political opponents and critics of the regime are fearful that nighttime curfews allow the military and police to pounce with impunity, an impunity that has a long history in Thailand (Haberkorn 2018) and that is further enabled by these measures.

What the American libertarians tragically fail to address is that their actions subvert the democracy they claim to uphold. Those who oppose curfews also demand controls over the policing of cities. That is very different from opposing a requirement to wear a mask to protect others from the risk of contagion. In the first case, those who protest are protecting the very basis of the freedom to criticise a policy. In the second, they are invoking a highly mythologised rendition of a national foundation myth of liberation from Great Britain - a country that, ironically, seeks images of redemption in its own mythologised creation of eternal democracy (Magna Carta and the Mother of Parliaments).

Freedom - social freedom - faces a terrible pandemic of its own. Ostensibly identical to the virtuous condition it mimics, this virus is the freedom of social irresponsibility. The more it spreads, the more difficult it is to stop. Liberty is not ipso facto a noble ideal. Its virtue depends on others, such as generosity, inclusiveness and moral courage. The kind that operates in molecular fashion by bonding with those social values is what makes us see in a casual nod from a stranger on the street, or in an empathising gesture at a difficult moment, and especially when faced with the fragility of life, the true capacity of human beings to care for each other and thereby to realise themselves. There are multiple cultural variations on this theme, and they may look significantly difficult, but those who live by such mutual concern and accept the premise of difference as easily as that of mutuality - can recognise in those moments the transcendent commonality of human care. ${ }^{7}$

It was the breakdown of that understanding that opened the floodgates to fascism in the twentieth century. Is it too much to ask that we learn the lessons of history before it is too late? There are two pandemics raging around us, each feeding the other, each imitating the other in their shared attack on the intimacy of everyday sociability. Never was social consciousness more necessary for the survival of common humanity. Never was the idea of a social 
conscience more comprehensively threatened by a plague of selfishness, hatred and rage.

Michael Herzfeld is the Ernest E. Monrad Research Professor of the Social Sciences in the Department of Anthropology at Harvard University and served as the founding Director (2014-2018) of the Thai Studies Program at the Asia Center at Harvard University. $\mathrm{He}$ is Senior Advisor on Critical Heritage Studies to the International Institute for Asian Studies, Leiden, and Visiting Professor at Leiden University. He also holds honorary appointments at Shanghai International Studies University, Thammasat University and the University of Rome (La Sapienza). Author of 11 books (most recently Siege of the Spirits: Community and Polity in Bangkok, 2016) and Cultural Intimacy: Social Poetics and the Real Life of States, Institutions, and Societies, 2016), and producer of two ethnographic films about Rome, he was Lewis Henry Morgan Lecturer for 2018 (book version forthcoming, Duke University Press). He currently specialises in nationalism, bureaucracy, craft production and apprenticeship, knowledge politics, and heritage conservation and its social impact (with a comparative focus on Europe and Asia).

E-mail: herzfeld@wjh.harvard.edu

\section{Notes}

1. 'I am not a dog lover. A dog lover to me means a dog that is in love with another dog' (Thurber 1994).

2. See especially Heath Cabot's (2019) biting commentary.

3. See my earlier discussions of racism, populism and cultural intimacy (Herzfeld 2016, 2019).

4. On everyday ethics, see, for example, Lambek (2015).

5. Ironically, the term was coined, not by an American, but by a British politician, Conservative Minister of the Environment Nicholas Ridley, in 1980. On its implications for planning, see Dear (1992); and Fischel (2001).

6. On methodological nationalism, see Wimmer and Glick Schiller (2002).

7. See, for example, Aulino (2019) on Buddhist Thailand and Kleinman (2019) on the United States.

\section{References}

Aulino, F. (2019), Rituals of Care: Karmic Politics in an Aging Thailand (Ithaca, NY: Cornell University Press).
Cabot, H. (2019), 'The Business of Anthropology and the European Refugee Regime', American Ethnologist 46, no. 3: 261-275, doi:10.1111/amet.12791.

Collinson, S., and C. Hu (2020), 'The World Isn't Laughing at America - It's Pitying Us', CNN, 29 June, https://www.cnn.com/2020/06/28/world/ meanwhile-in-america-june-26-intl/index.html.

Dear, M. (1992), 'Understanding and Overcoming the NIMBY Syndrome', Journal of the American Planning Association 58, no. 3: 288-300, doi:10.1080/01944369 208975808.

De Genova, N., (ed.) (2017), The Borders of 'Europe': Autonomy of Migration, Tactics of Bordering (Durham, NC: Duke University Press).

Fischel, W. A. (2001), 'Why Are There NIMBYs?' Land Economics 77, no. 1: 144-152, doi:10.2307/3146986.

Gebrekidan, S. (2020), 'For Autocrats, and Others, Coronavirus Is a Chance to Grab Even More Power', New York Times, 30 March, https://www.nytimes .com/2020/03/30/world/europe/coronavirus-govern ments-power.html.

Glaeser, A. (2004), 'Monolithic Intentionality, Belonging, and the Production of State Paranoia: A View through Stasi onto the Late GDR', in Off Stage / On Display: Intimacy and Ethnography in the Age of Public Culture, (ed.) A. Shryock (Stanford, CA: Stanford University Press), 244-276.

Haberkorn, T. (2018), In Plain Sight: Impunity and Human Rights in Thailand (Madison: University of Wisconsin Press).

Herzfeld, M. (1985), The Poetics of Manhood: Contest and Identity in a Cretan Mountain Village (Princeton, NJ: Princeton University Press).

Herzfeld, M. (2016), Cultural Intimacy: Social Poetics and the Real Life of States, Societies, and Institutions, 3rd ed. (New York: Routledge).

Herzfeld, M. (2019), 'How Populism Works', in Democracy's Paradox: Populism and Its Contemporary Crisis, (eds) B. Kapferer and D. Theodossopoulos (Oxford: Berghahn), 122-138.

Holmes, K., and Cole, D. (2020), 'Trump Calls Fauci “a Little Bit of an Alarmist' as Coronavirus Cases Rise', CNN Politics, 19 July, https://www.cnn.com/2020/ 07/19/politics/trump-fauci-alarmist-coronavirus/ index.html.

Kalantzis, K. (2019), Tradition in the Frame: Photography, Power and Imagination in Sfakia, Crete (Bloomington: Indiana University Press).

Kleinman, A. (2019), The Soul of Care: The Moral Education of a Husband and a Doctor. (New York: Viking).

Lambek, M. (2015), The Ethical Condition: Essays in Action, Person, and Value (Chicago: University of Chicago Press). 
Rogers, K. (2020), 'After Attacks from Trump Aides, Fauci Says "Let's Stop This Nonsense" and Focus on Virus', New York Times, 15 July, https://www .nytimes.com/2020/07/15/us/politics/fauci-navarrocoronavirus.html.

Rozakou, K. (2017), 'Solidarity \#Humanitarianism: The Blurred Boundaries of Humanitarianism in Greece', Etnofoor 29, no. 2: 99-104, https://www.jstor.org/ stable/26296172.

Santiago, F. (2020), 'Florida Governor Owes an Apology for Blaming COVID-19 Spike on "Hispanic" Workers', Miami Herald, 24 June, https://www .miamiherald.com/news/local/news-columns-blogs/ fabiola-santiago/article243725817.html.
Sopranzetti, C. (2017), Owners of the Map: Motorcycle Taxi Drivers, Mobility, and Politics in Bangkok (Berkeley: University of California Press).

Thurber, J. [1939] (1994), 'I Like Dogs', in People Have More Fun Than Anybody (New York: Harcourt Brace), https://quotepark.com/quotes/1891629-jamesthurber-i-am-not-a-dog-lover-a-dog-lover-to-memeans-a-do/ (accessed 19 July 2020).

Wimmer, A., and N. Glick Schiller (2002), 'Methodological Nationalism and Beyond: Nation-State Building, Migration and the Social Sciences', Global Networks 2, no. 4: 301-334, doi:10.1111/1471-0374.00043. 